\title{
Contents Volume 1
}

No. 1

Risk management and good medicine

M.N.G. Dukes

The development of medical patient-injury risk management programs: the

American experience

W.J. Curran (U.S.A.)

A study of risk evaluation and quality control in anaesthesia

S.E. Gisvold, P.O. Molaug, S. Hallan and V. Arnulf (Norway)

The Milton Silverman Award

The psychological and social implications of serum cholesterol screening

T. Tijmstra (The Netherlands)

Doctors should admit their mistakes

T. Smith (U.K.)

Medical devices: a new approach to the quality dilemma

R. Karlsen (Norway)

The Medic-Alert Foundation - a non-profit health organization which protects and saves lives

D.J.C. Gilchrist

Ethical aspects of drug testing in AIDS H.P. Lambert (U.K.)

Emergency trauma care: cultural or religious objections to treatment

W.J. Curran, S.J. Reiser and E. Heitman (U.S.A.)

Health quackery - holding back the tide P. Skrabanek (Ireland)

Short Reports

Meeting Report

Forthcoming Meetings

Reviews

Hippocrates $\quad 83$

$\begin{array}{lr}\text { Information for Authors } & 89\end{array}$ 
No. 2

Announcement from the Publisher

A study of drug utilization in pregnancy in the light of known risks: is there room for improvement?

L.T.W. de Jong-van den Berg, P.B. van den Berg, P.W.J. Peters and F.M. Haaijer-Ruskamp (The Netherlands)

Communicating with the unconscious patient

A.T. Bergenheim, R. Henriksson and M. Knibestöl (Sweden)

Risks of donor insemination

C.L.R. Barratt and I.D. Cook (U.K.)

Was the obstetric care negligent?

C.E. James (U.K.)

Medical devices and public policy: the pharmaceuticals analogy

C.W.D. van Gruting (The Netherlands)

Vena cava superior syndrome associated with total parenteral nutrition

S. Svane (Norway)

Missed diagnosis and delayed laparotomy in blunt abdominal trauma F. Naess, A. Nesbakken, K. Solheim, J. Pillgram-Larsen, T. Gerner and J.O. Stadaas (Norway)

Was the obstetric care negligent? Judgement and comments

The European Ethical Review Committee P.N. Bennett and J.M. Faccini (France)

Improving drug safety: a joint responsibility W.P. von Wartburg (Switzerland)

Forthcoming Meetings

First World Congress on Safety in Medical Practice

Persistent trophoblastic tissue following conservative surgery for ectopic pregnancy

P. Smith (Sweden)

Sacro-iliitis and misuse of anabolic steroids Y. Lindroth, B.U. Hansen and R. Holst (Sweden)

Frequency and causes of bucco-lingual-facial dyskinesias in the elderly D. Strubel, S. Bimboes, F. Kuntzmann and M. Berthel (France)

Cardiac arrest after intracoronary injection of diltiazem J. Allal, D. Coisne and R. Barraine (France) 
No. 3

Diethylstilbestrol, teratogenesis, and carcinogenesis: medical/legal implications of its long-term sequelae, including third generation effects

H.T. Lynch, T. Quinn and M.J. Severin (U.S.A.)

Defective medicines: unavoidable danger or unacceptable risk?

C. Newdick (U.K.)

Medical accidents: research in the U.K.

C.A. Vincent, K. Gannon, M. Ennis and R.J. Audley (U.K.)

Risk and safety of contact lenses

B.C.P. Polak and W.H. Beekhuis (The Netherlands)

Some safety aspects of in vitro fertilization and pre-embryo freezing J.M. Maltau (Norway)

DES: a drug with consequences for healthy policy (Meeting Report)

AIDS treatment and patient pressures (Hippocrates)

Reviews of books and studies

Information for Authors

Announcement from the Publisher

No. 4

The American medical malpractice system: impediments to effective change M.B. Kapp (U.S.A.)

Safety and risk in a context of culture. An anthropological perspective on the relativity of health and care

L. Sachs (Sweden)

Treatment of hypertension as a risk factor in a prospective study H.L. Thürmer, P.G. Lund-Larsen, A. Tverdal and D.S. Thelle (Norway)

The use of prescribed medications for suicide

D. Lester (U.S.A.)

Hippocrates

Reviews of books and studies 287

Contents Volume 1 295

Information for Authors 299

Announcement from the Publisher 